DE LA RECHERCHE À L'INDUSTRIE

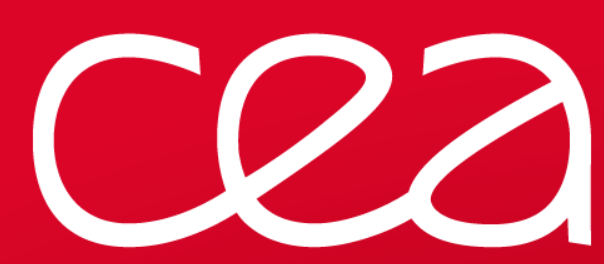

\section{Innovative Coupled Hydrometallurgical and Pyrochemical Processes for Rare Earth Recycling}

E. Andreiadis, V. Blet, J. Serp, M. Miguirditchian

CEA, Atomic Energy and Alternative Energies Commission, Research Department on Mining and Fuel Recycling Processes,

Marcoule, France 


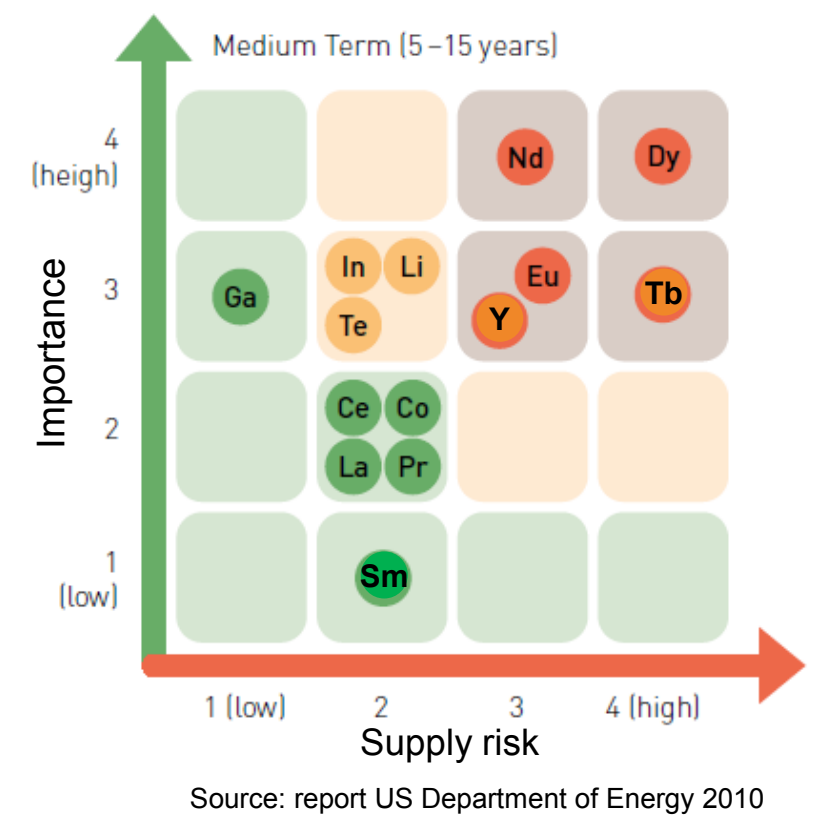

\section{Possible solutions to decrease REE criticality}

Reducing consumption (shift in technology)

$>$ Substitution by other non-critical metals

$>$ Diversifying supply

$>$ Primary and secondary sources (new mines, tailings...)

$>$ Recycling (scraps, urban mine)

\section{Rare earth elements are critical raw materials}

$>$ Demand growing, especially for magnets (> 7\% per year for $\mathrm{Nd}$ )

$>$ Accelerated growth of HEV/EV market $(+30 \%$ in 2017)

$>$ Global REO production in 2018 estimated at $175 \mathrm{kT} / \mathrm{yr}$

$>$ Production chain concentrated in China (mining, separation, downstream manufacturing, R\&D capacity): $\mathbf{8 0} \%$ world REO supply $>$ Currently no European mine in operation

$>$ Significant price volatility during the last 10 years

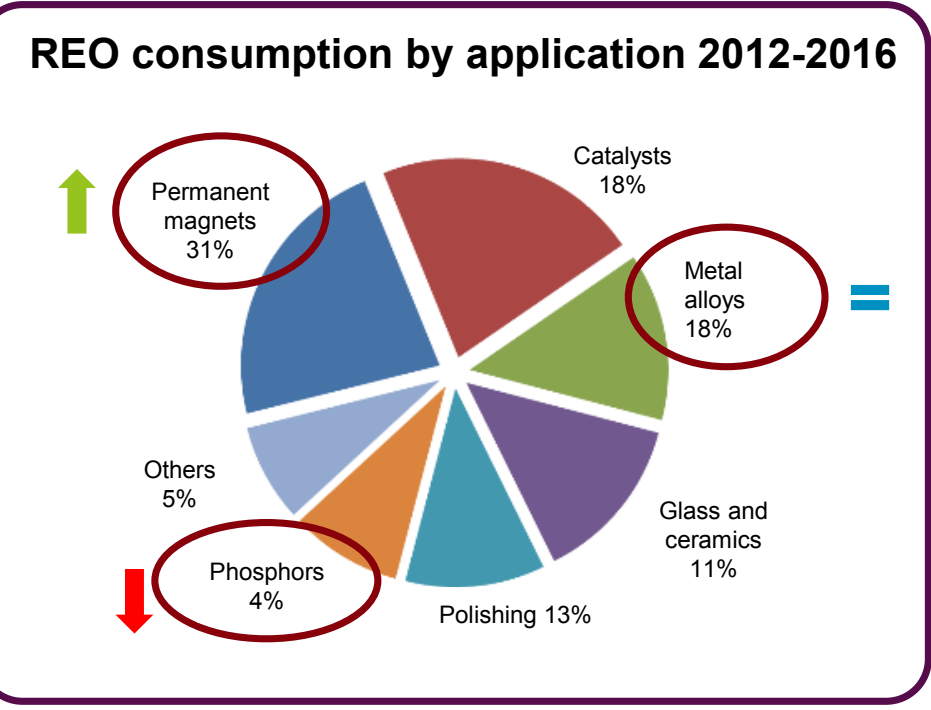

References: Roskill 2015, IMCOA 2017 


\section{Advantages of recycling}

$>$ Target only the most critical rare earths

$>$ No issues with radioactive elements $(235 \mathrm{U}, 238 \mathrm{U}, 232 \mathrm{Th})$

$>$ Lower environmental footprint (public acceptance)

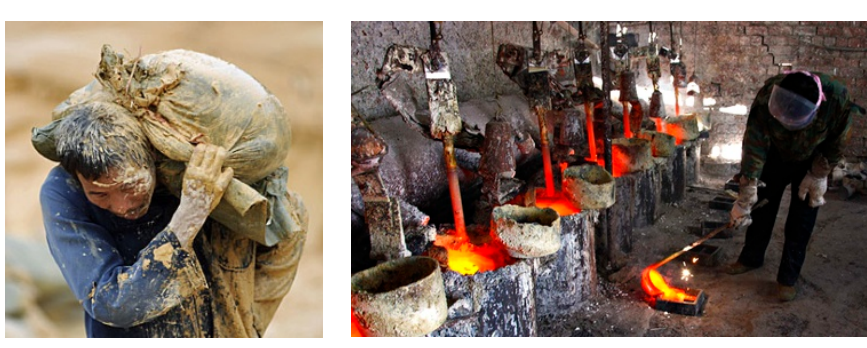

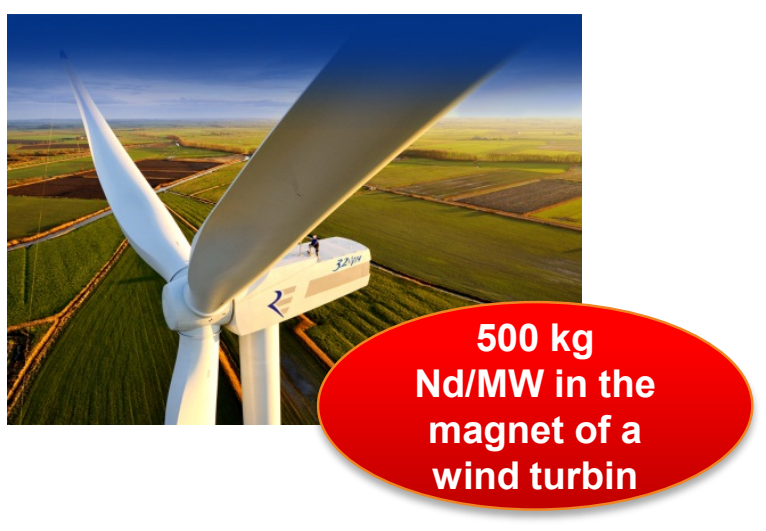

Opportunities

$>$ Competences and expertise of the European recycling industry

$>$ Leveraging on the urban mine

$>$ Development of a circular economy

$>$ Positive economic and environmental impact
Challenges

$>$ Insufficient and untargeted collection of waste sources

$>$ Difficult recovery of REE-containing fractions

$>$ Difficult separation of individual REE

$>$ No regulatory incentives for recycling WEEE

$>$ Low economic interest in line with current market prices
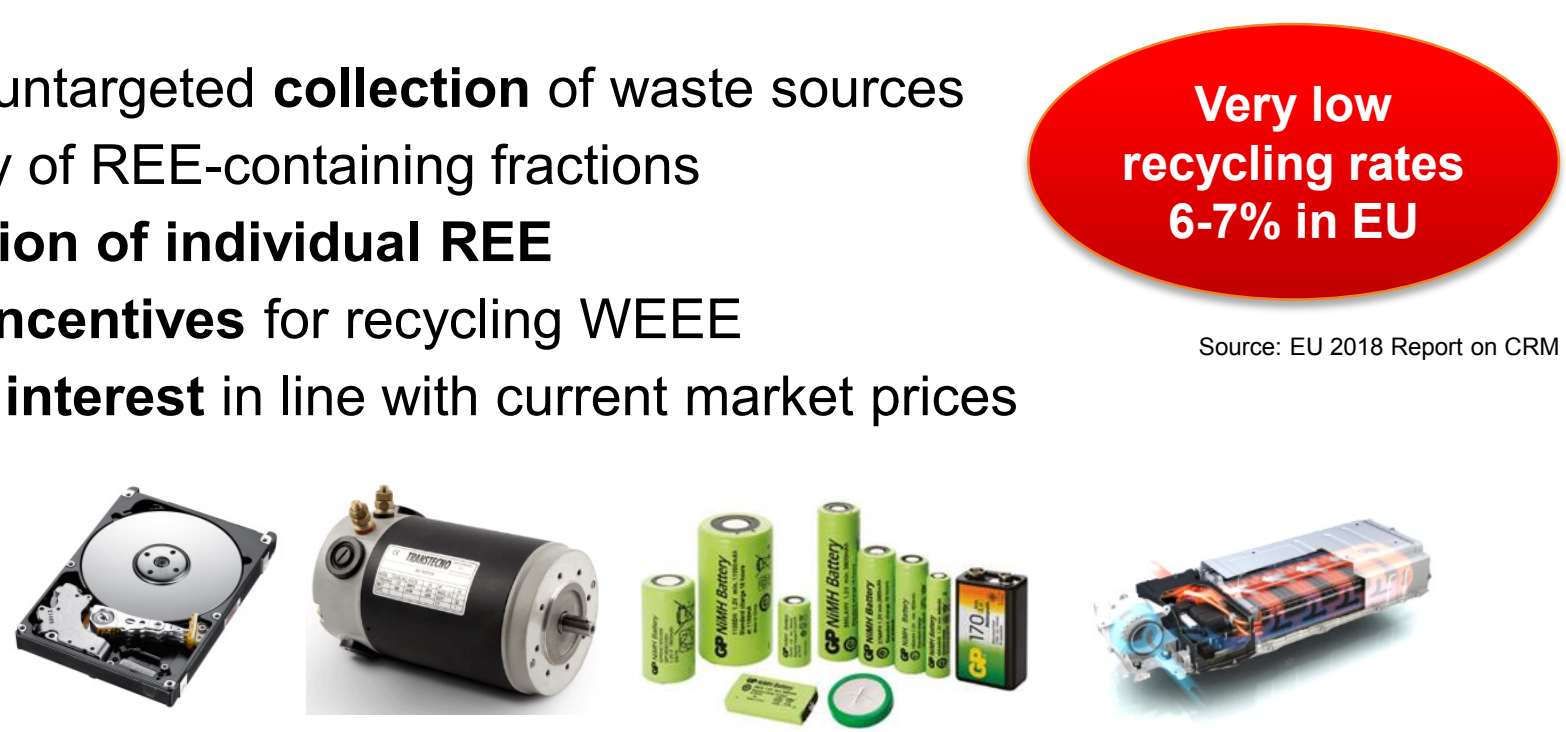

Recovering REE from NdFeB magnets and $\mathrm{Ni}-\mathrm{MH}$ batteries

$>$ Magnets are the most important REE application

$>$ Battery recycling is regulated + immediate availability 


\section{Flowchart for REE recovery from $\mathrm{NdFeB}$ magnets}

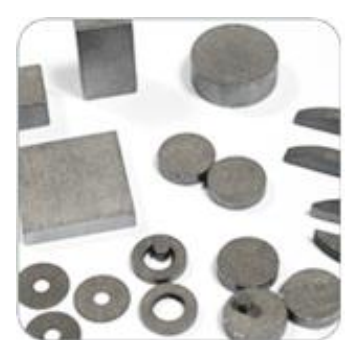

High REE concentration (25\% Nd, 5\% Pr, 2-8\% Dy)
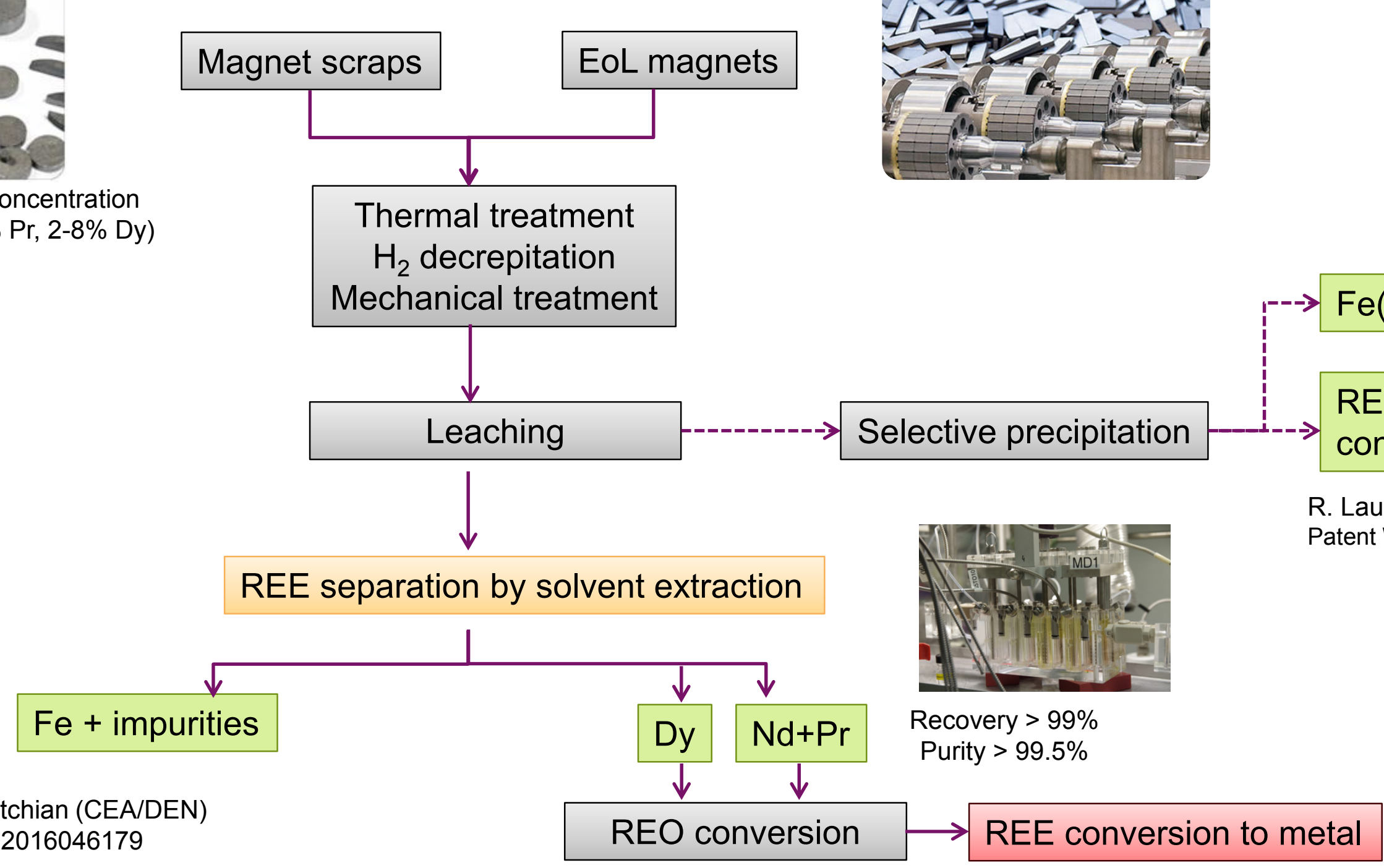

M. Miguirditchian (CEA/DEN)

Patent WO2016046179

Thermal treatment

$\mathrm{H}_{2}$ decrepitation

Mechanical treatment

REO mixed concentrate

R. Laucournet (CEA/DRT) Patent WO2014/06459 
Challenge: excellent affinity and selectivity for REE in the presence of $\mathrm{Fe}^{3+}$

- Screening of several commercially-available extracting molecules

- Selection of diglycolamides (TODGA) class of solvating extractants

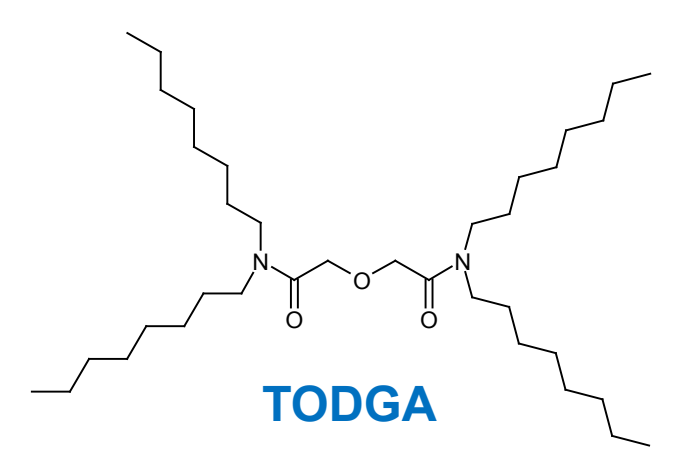

Sasaki et al, 2002

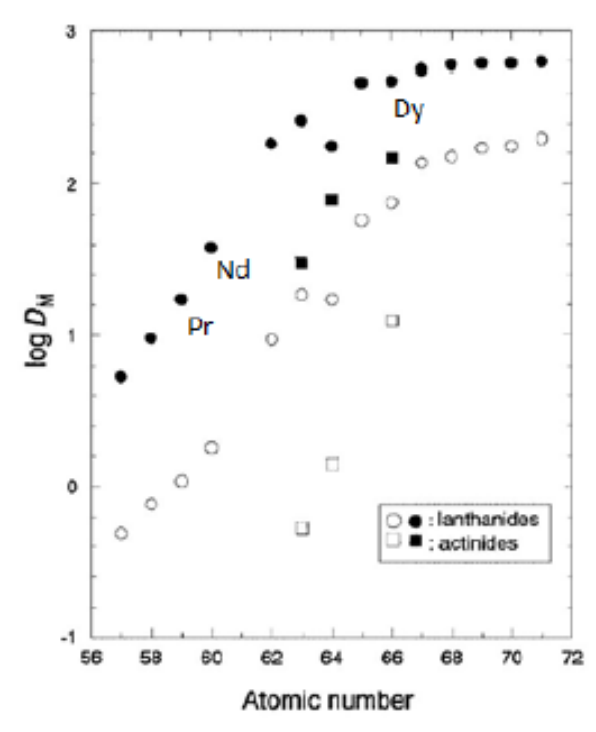

$\mathrm{HNO}_{3}, 0.1 \mathrm{M}$ TODGA

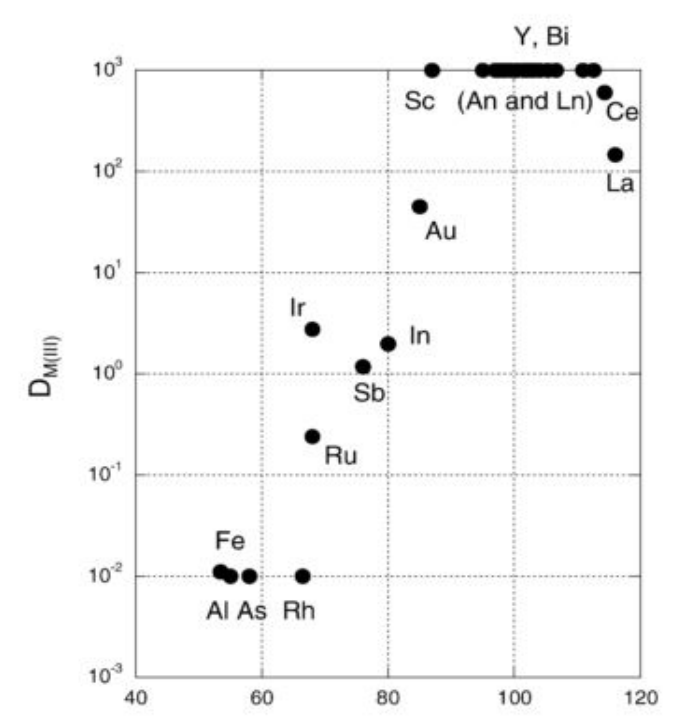

ionic radius/ pm
$\mathrm{HNO}_{3} 3 \mathrm{M}, 0.1 \mathrm{M}$ TODGA

Extraction capacity inversely proportional to $\mathrm{RE}^{3+}$ ionic radius

- Excellent extraction of heavy RE (Dy) and good intra-REE separation factor in nitric acid media

Excellent selectivity with respect to boron and transition metals $\left(\mathrm{Fe}^{3+}, \mathrm{Ni}^{2+}, \mathrm{Co}^{2+}\right)$ 
- Tests on synthetic and genuine magnet solutions in nitric acid

- Quantitative extraction of Dy (D > 100)

- Efficient separation of RE / transition metals ( $\mathrm{Fe}, \mathrm{Co}, \mathrm{Ni} . .$. and $R E / R E$ in a large range of acidity $(0.4$ to $5 \mathrm{M})$

- No $3^{\text {rd }}$ phase formation in process conditions

Quantitative stripping of Nd and Dy at low acidity (pH 2-3)
Solvent formulation:

$0.2 \mathrm{M} \mathrm{TODGA}+5 \%$ octanol / HTP

Synthetic aqueous solution composition:

\begin{tabular}{|l|l|l|l|l|l|l|l|l|}
\hline Elément & $\mathrm{B}$ & $\mathrm{Fe}$ & $\mathrm{Co}$ & $\mathrm{Ni}$ & $\mathrm{Cu}$ & $\mathrm{Pr}$ & $\mathrm{Nd}$ & $\mathrm{Dy}$ \\
\hline
\end{tabular}

\begin{tabular}{l|l|l|l|l|l|l|l|l|}
\hline $\mathrm{g} / \mathrm{l}$ & 0.5 & 35 & 0.2 & 0.8 & 0.5 & 3.1 & 12.5 & 0.3
\end{tabular}
Distribution coefficients $D_{m}$

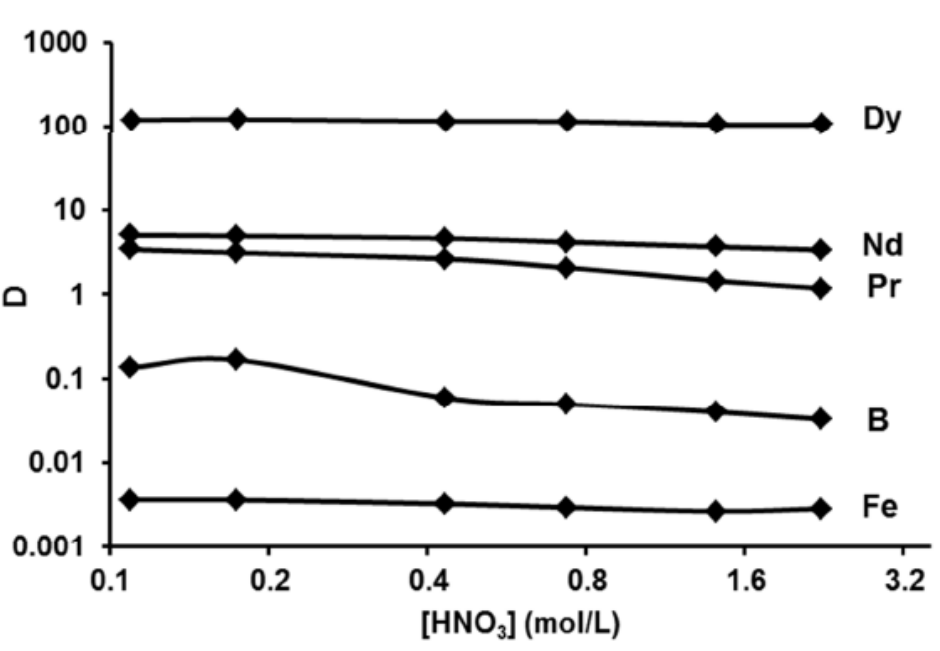

Separation factors $\mathrm{SF}_{\mathrm{M} / \mathrm{M}}$

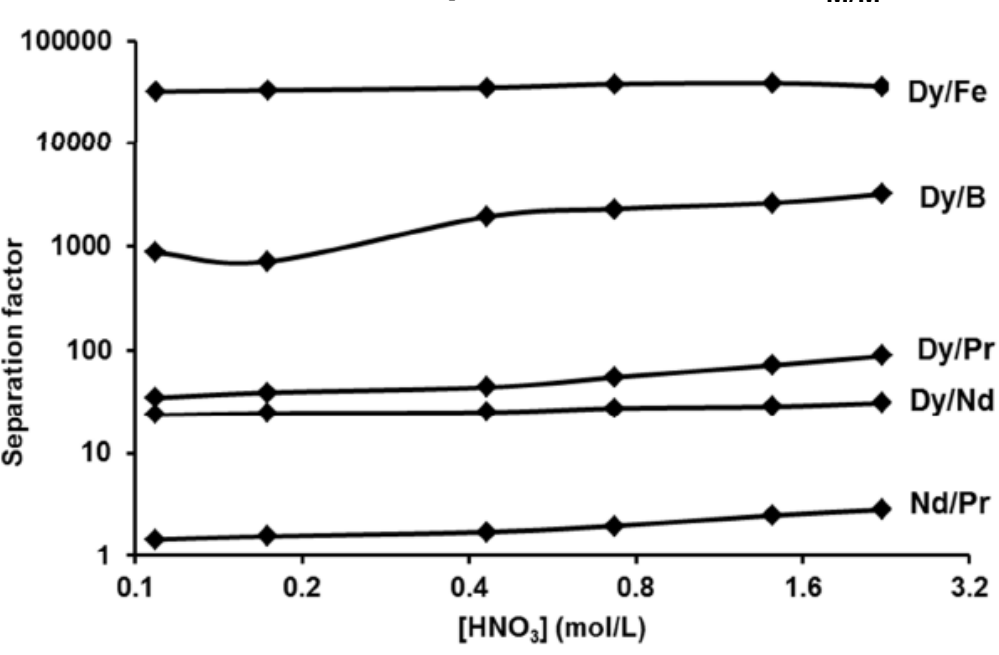

Confirmation of the potential of TODGA for selective Dy recovery from $\mathrm{NdFeB}$ magnet solutions 
Elaboration of a phenomenological model from experimental batch data

- Representation of distribution equilibria $\mathrm{HNO}_{3}$-Oct, $\mathrm{HNO}_{3}$-TODGA, Ln-NO ${ }_{3}$-TODGA

$=\left(\mathrm{HNO}_{3}\right)(\text { octanol })_{2}$

$=\left(\mathrm{HNO}_{3}\right)_{\mathrm{m}}(\mathrm{TODGA})$ with $\mathrm{m}=1$ to 3

- $\mathrm{M}\left(\mathrm{NO}_{3}\right)_{3}(\mathrm{TODGA})_{\mathrm{n}}$ with $\mathrm{n}=3$ for Dy, $\mathrm{Nd}, \mathrm{Pr}, \mathrm{Fe}$

$K^{\prime}{ }_{n}=\frac{\left[\overline{\left\{T R\left(\mathrm{NO}_{3}\right)_{3}, \mathrm{TODGA}_{n}\right\}}\right]}{\left.\gamma_{\mathrm{TR}\left(\mathrm{NO}_{3}\right)_{3}} \cdot\left[\mathrm{TR}_{\mathrm{NO}} \mathrm{NO}_{3}\right)_{3}\right] \cdot[\overline{\mathrm{TODGA}}]^{n}}$

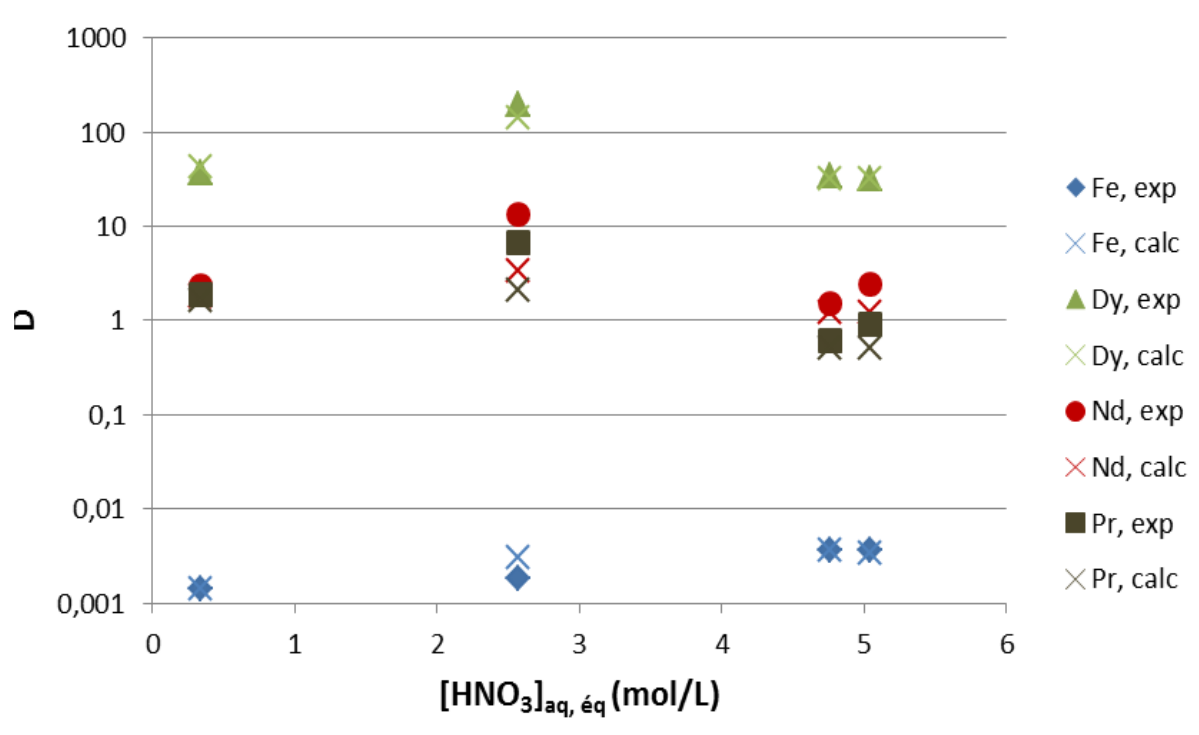

Activity coefficients taken into account in aqueous phase

Good agreement between extraction experiments and calculated values for both synthetic and real solutions

- Implementation of the model in the CEA PAREX simulation code and calculation of flowsheets

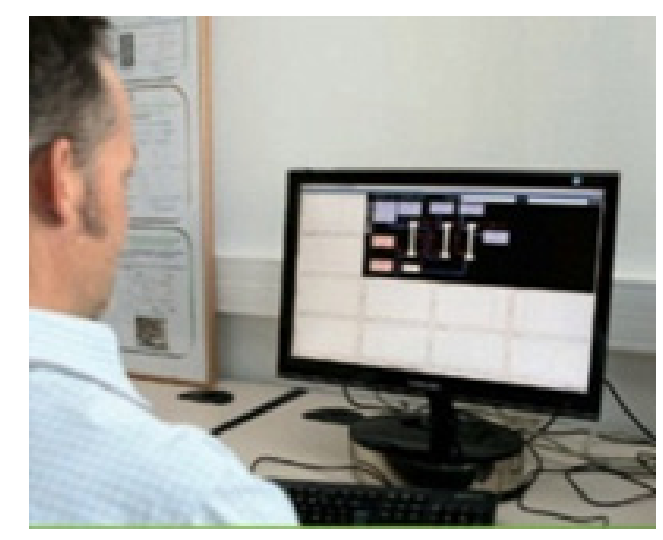




\section{Pilot test $n^{\circ} 1$}

- Selective extraction of all REE followed by Dy/Nd partitioning

Compact 24-stage lab-scale mixer-settler setup at $100 \mathrm{~mL} / \mathrm{h}$

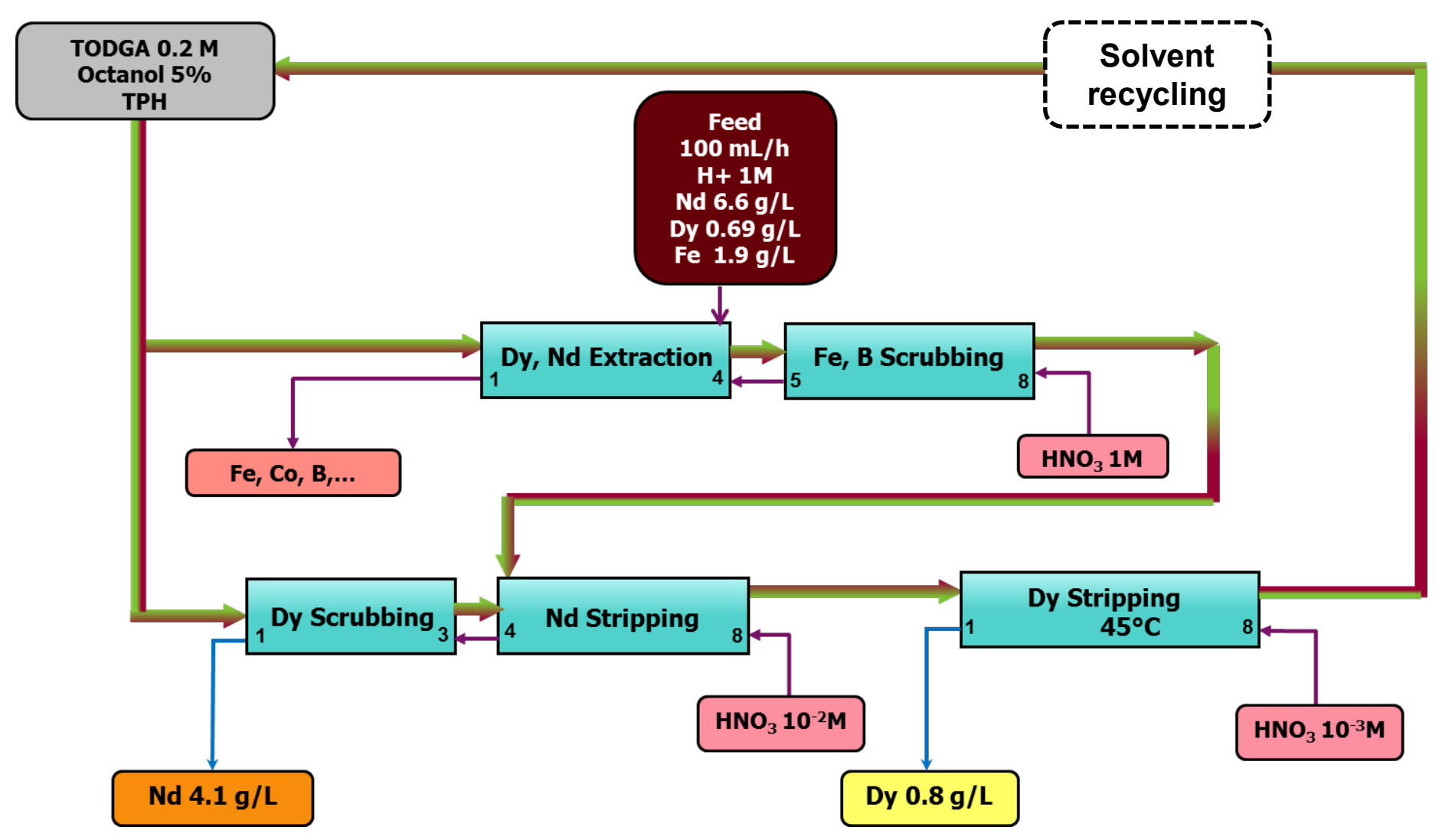

Test runned for $32 \mathrm{~h}$

Very good hydrodynamic behavior

UV-vis on-line analysis (for $\mathrm{Nd}$ ) and ICP-AES measurements for $\mathrm{Dy}, \mathrm{Nd}$, Fe

- Excellent recovery of REE with very high purity

- $\mathrm{Nd}+\mathrm{Pr}$ recovery $>99.98 \%$ with purity $>99.99 \%$

- Dy recovery $96.7 \%$ with purity $99.96 \%$ 


\section{Pilot test $n^{\circ} 2$}

- Selective extraction of only Dy followed by stripping

nd \& Pr collected in the raffinate for further $2^{\text {nd }}$ cycle process

Compact 16-stage lab-scale mixer-settler setup at $200 \mathrm{~mL} / \mathrm{h}$

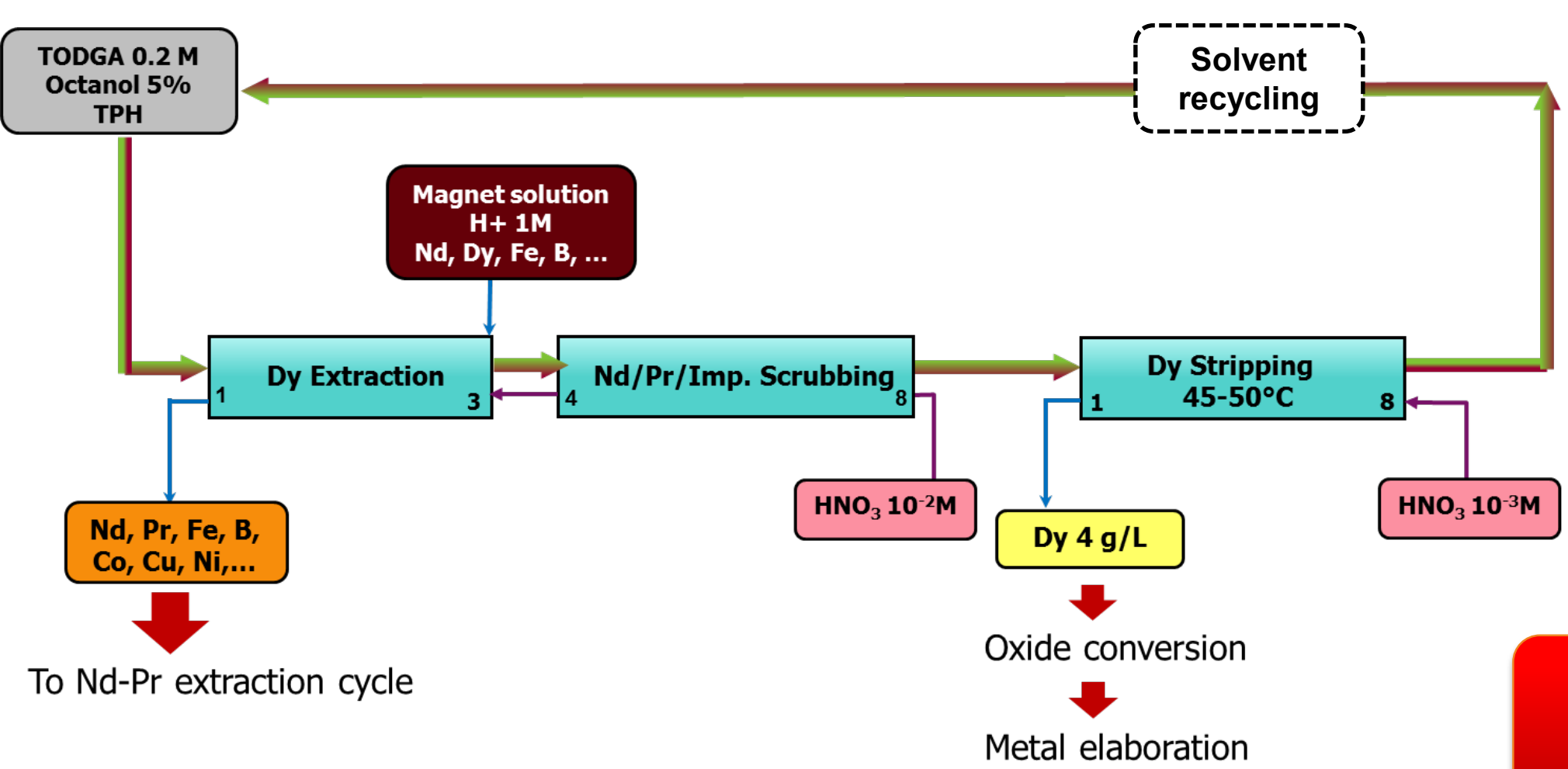

E Test runned for $20 \mathrm{~h}$

Very good hydrodynamic behavior

UV-vis on-line analysis (for $\mathrm{Nd}$ ) and ICP-AES measurements for Dy, Nd, Fe

Excellent recovery of Dy $(99.7 \%)$ with very high purity

- Upgrade Dy from 0.69 to $4.05 \mathrm{~g} / \mathrm{L}(\times 6)$

Metal elaboration

Validation of hydrometallurgical process flowsheets at TRL 5 level 

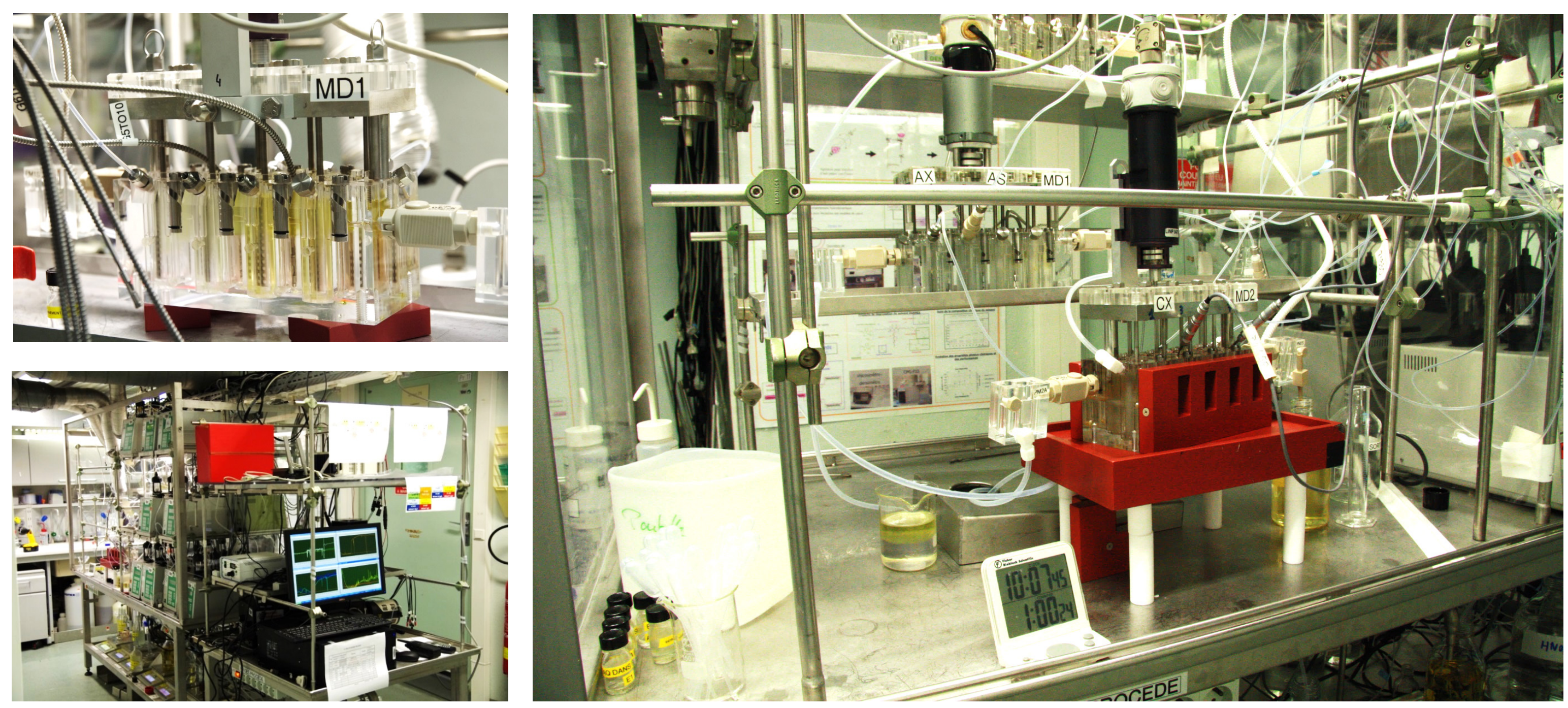
$\overline{A N} \mathrm{R}$

REPUTER project

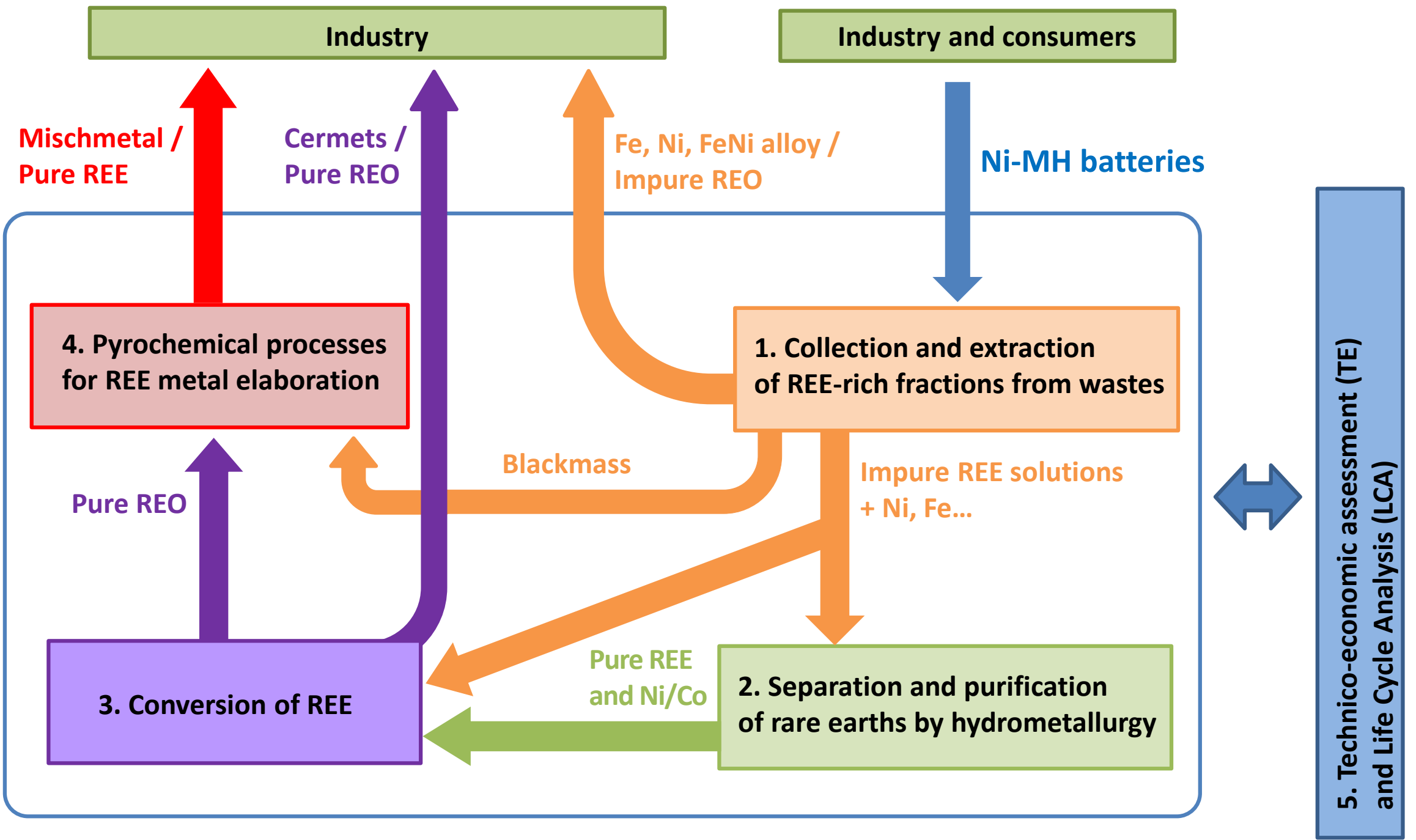




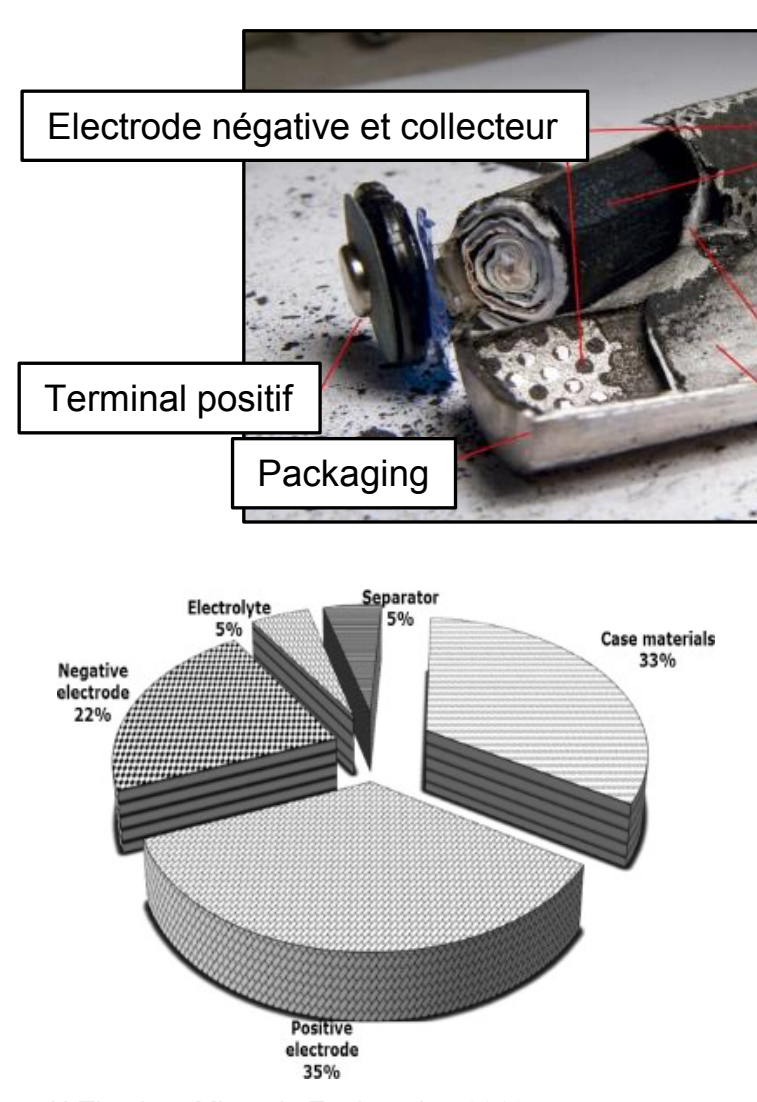

Al-Thyabat, Minerals Engineering 2013
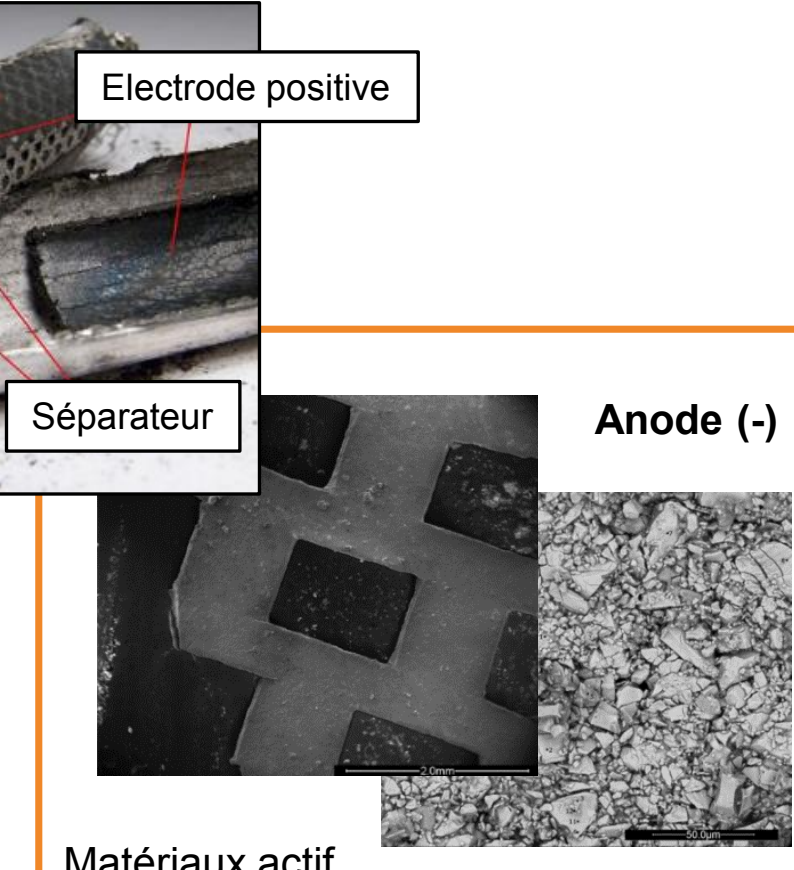

$\mathrm{MmB}_{5} \&\left(\mathrm{Y}_{2} \mathrm{O}_{3}, \mathrm{Yb}_{2} \mathrm{O}_{3}\right.$, liants $)$

$\mathrm{Mm}=\mathrm{La}_{0,62} \mathrm{Ce}_{0,27} \mathrm{Pr}_{0,03} \mathrm{Nd}_{0,08}$

$\mathrm{B}_{5}=\mathrm{Ni}_{3,55} \mathrm{Co}_{0,75} \mathrm{Mn}_{0,4} \mathrm{Al}_{0,3}$

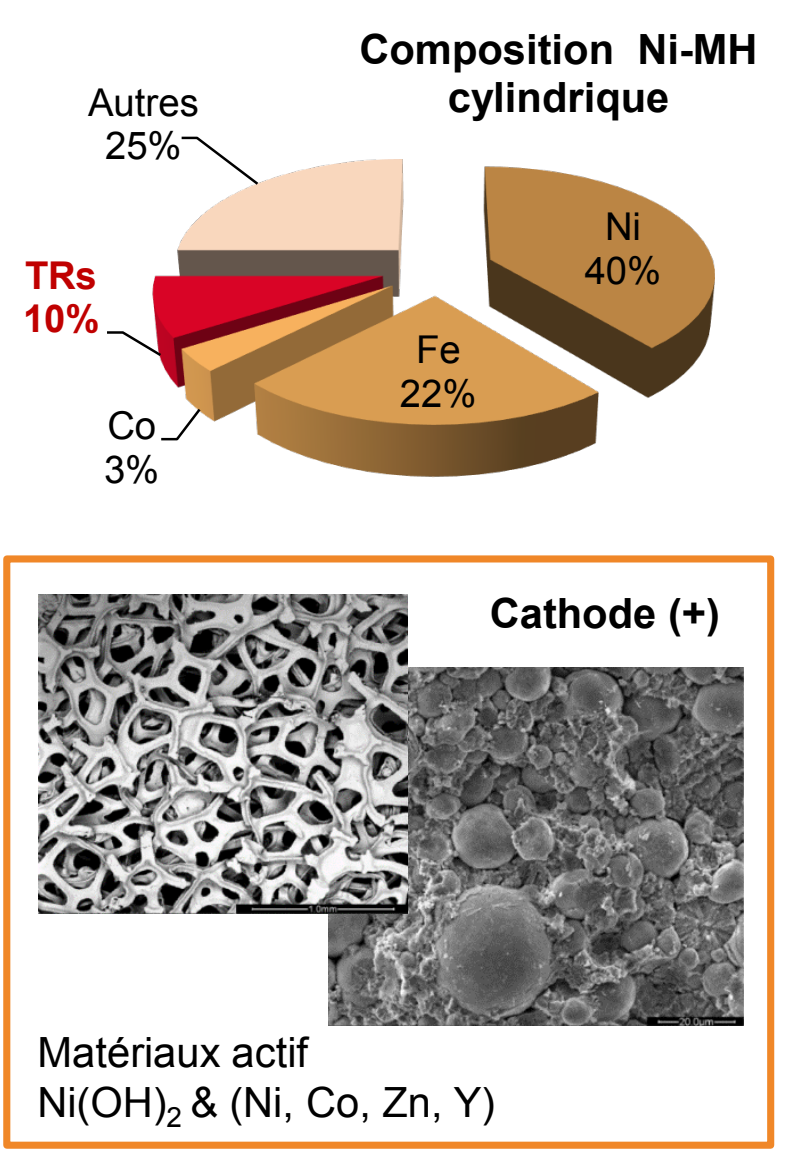




\section{Physical and mechanical treatment of batteries}

- Adapting an existing NiMH recycling process for the recovery of RE-rich fractions

- Production of a $10 \mathrm{~kg}$ final sample
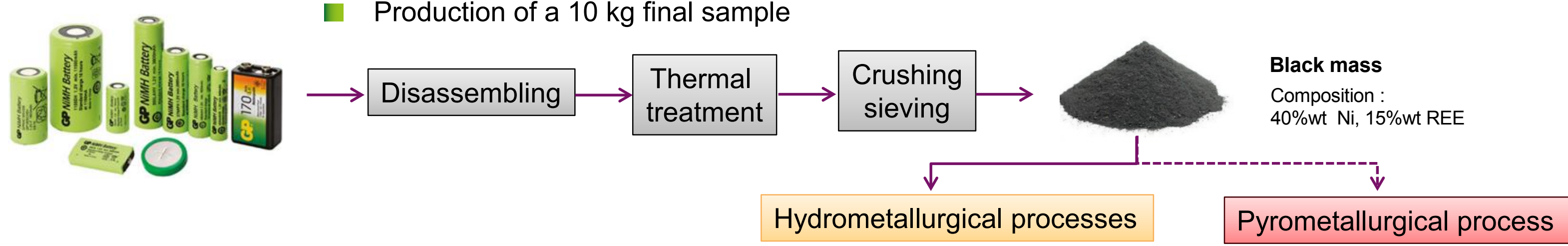

\section{Hydrometallurgical treatment of the black mass}

- Choice of acids and leaching conditions compatible with an industrial approach

- Total digestion (REE $+\mathrm{Ni}, \mathrm{Co} \ldots$ )

- Excellent yield for $\mathrm{HNO}_{3}$ and $\mathrm{HCl}$ acid solutions at controlled $\mathrm{pH}$

- Selective leaching (only $\mathrm{Ni}, \mathrm{Co} . .$. )

- Precipitation of REE in sulfuric acid solution

- Redissolution of sulfate precipitates and further conversion
Lixiviation solution composition ( $\mathrm{g} / \mathrm{L})$ $\mathrm{HNO}_{3} 1 \mathrm{M}(\mathrm{pH}=0)$, rt, $\mathrm{S} / \mathrm{L}=10 \%$

\begin{tabular}{cc}
\hline $\mathrm{La}$ & 4.6 \\
$\mathrm{Ce}$ & 7.7 \\
$\mathrm{Pr}$ & 0.5 \\
$\mathrm{Nd}$ & 2.0 \\
$\mathrm{Ni}$ & 40.0 \\
$\mathrm{Co}$ & 5.2 \\
$\mathrm{Mn}$ & 2.1 \\
$\mathrm{Fe}$ & 3.3 \\
\hline
\end{tabular}


- Choice of TODGA extractant for selective REE extraction

- Tests on simulated and real solutions in $\mathrm{HNO}_{3}$ and $\mathrm{HCl}$ media

- Optimisation of extraction and stripping conditions

\section{REE extraction function of TODGA concentration}

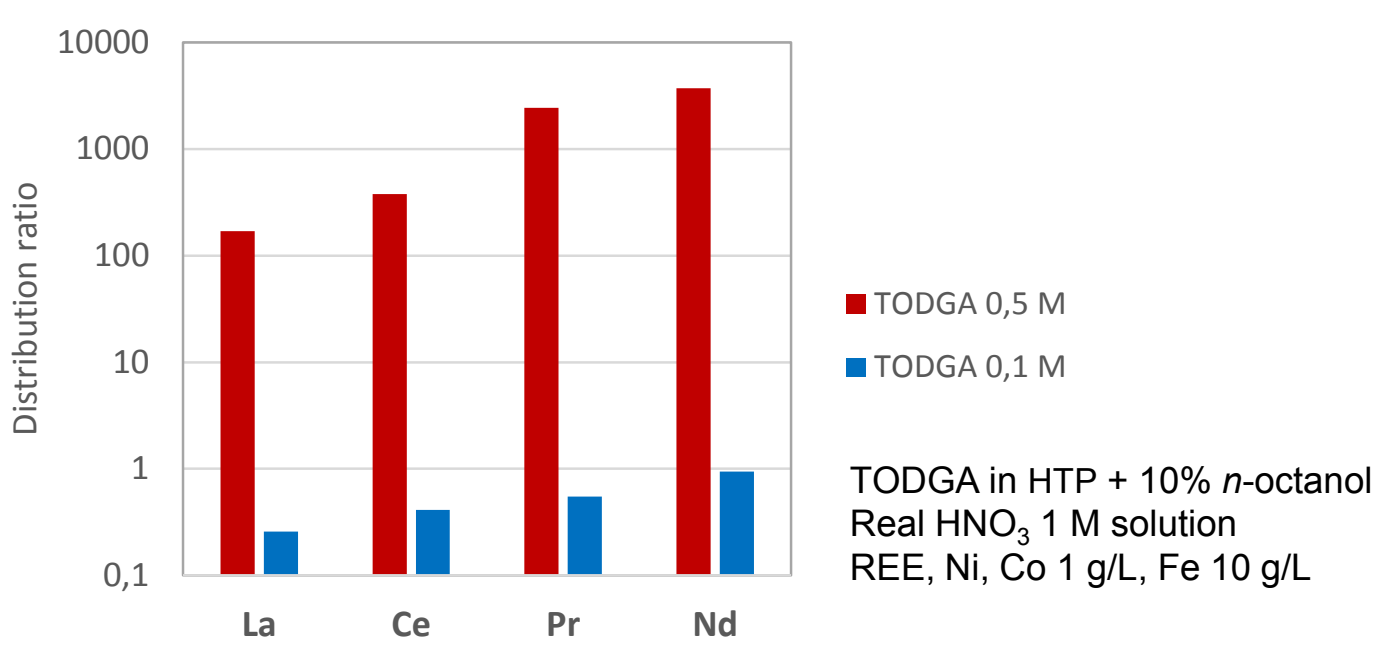

Excellent extraction of light REE upon increasing TODGA concentration

- Very high selectivity (Ni, Co, Mn, Fe not extracted)

- Very high REE purity in the extract $>99 \%$ (after 1 contact, before scrubbing and stripping)

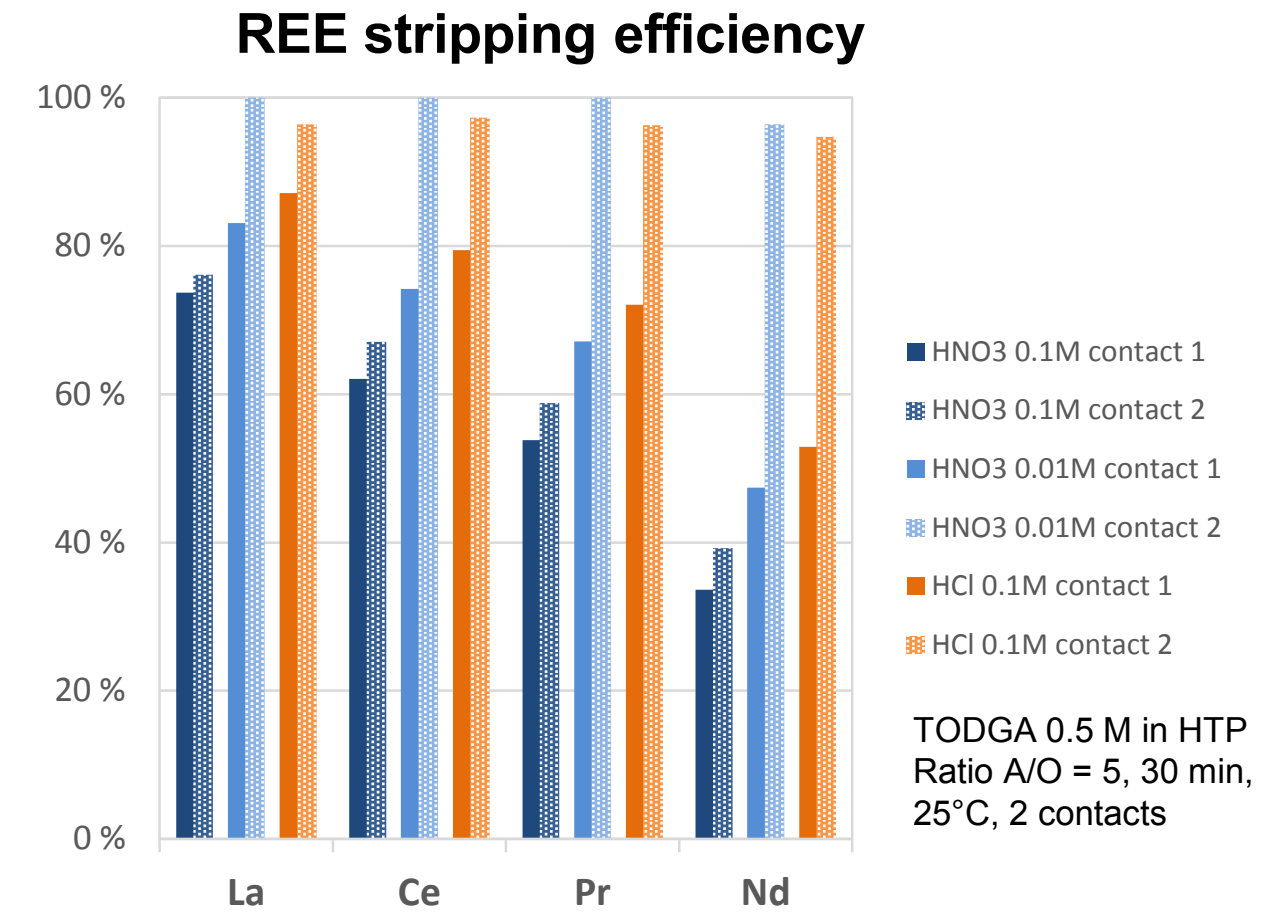

- Near-quantitative stripping of REE in 2 contacts with dilute acid at rt $\left(\mathrm{HNO}_{3} 0.01 \mathrm{M}\right.$ or $\left.\mathrm{HCl} 0.1 \mathrm{M}\right)$

Elowsheet calculation for the recovery of a purified mixed-REE solution in progress... 
Increase the amphiphilic character

- Short (hydrophilic) alkyl chains: $\mathrm{R}_{1}$

$\square$ Long (lipophilic) alkyl chains: $R_{2}$

> Improving the extraction of light REE

$>$ Increasing the selectivity towards transition metals (e.g. Fe, Ni)

$>$ Improving the REE extraction in sulfuric and hydrochloric acid media
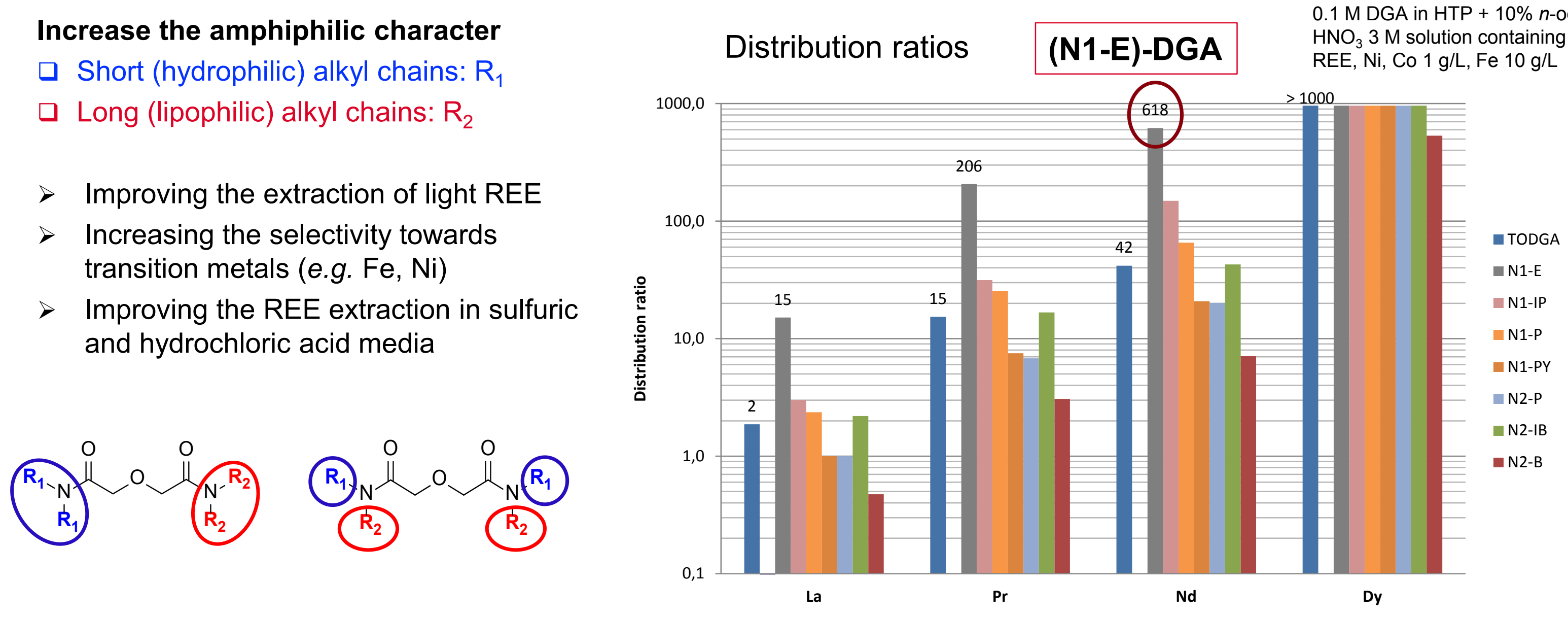

7 new DGAs synthesized

Excellent extraction of heavy REE ( $\left.D_{\text {Dy }}>1000\right)$

Increased extraction (x 15) of light REE for (N1-E)-DGA compared to TODGA 

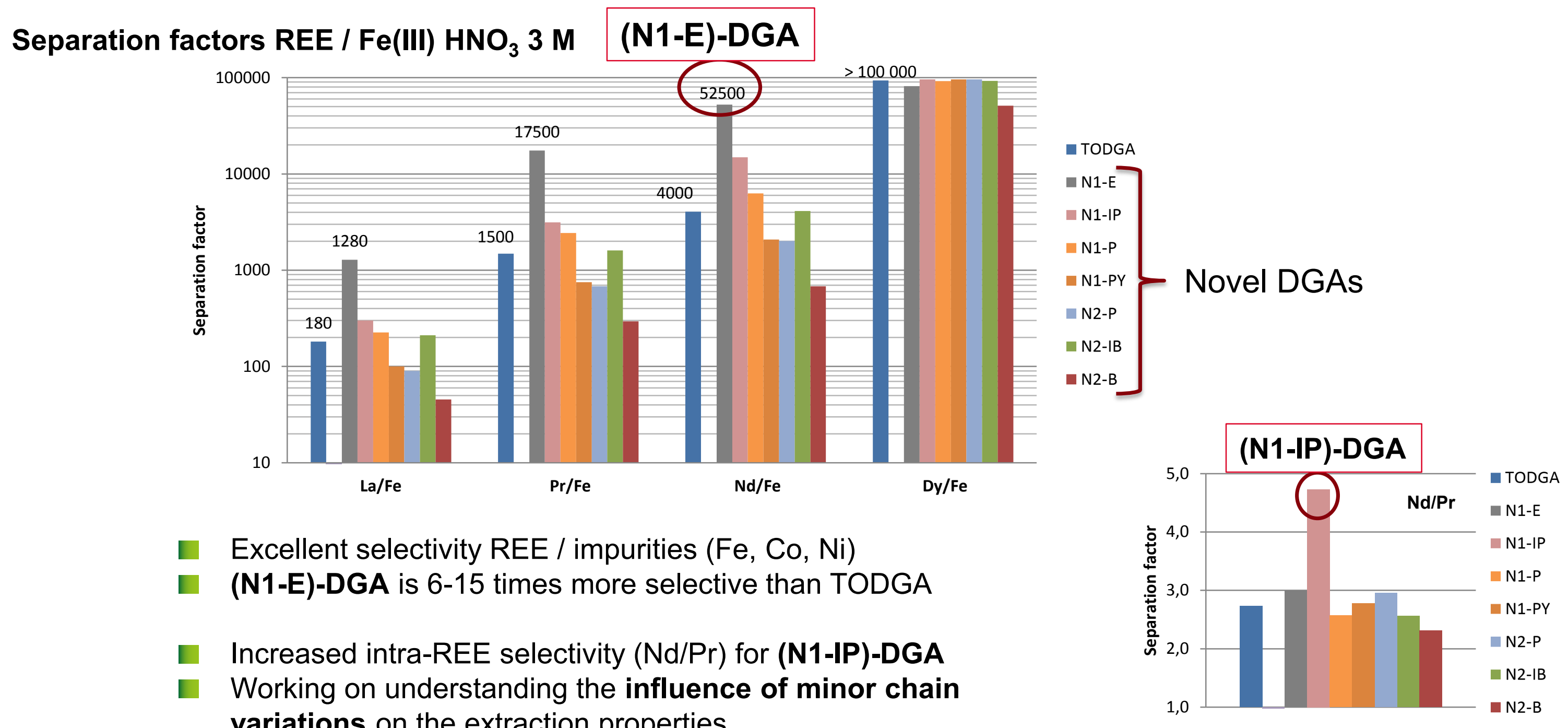

- Excellent selectivity REE / impurities ( $\mathrm{Fe}, \mathrm{Co}, \mathrm{Ni}$ )

(N1-E)-DGA is 6-15 times more selective than TODGA

- Increased intra-REE selectivity (Nd/Pr) for (N1-IP)-DGA

- Working on understanding the influence of minor chain variations on the extraction properties 


\section{Conversion of purified REE into a oxides}

Both for magnet or battery recycling, after the solvent extraction step

- Production of a highly homogeneous powder by oxalic precipitation

\section{Conversion of $\mathrm{Ni}$ and $\mathrm{REE}$ into cermets $\mathrm{Ni}-\mathrm{Ce}(\mathrm{Ln}) \mathrm{O}_{2}$ (WAR process)}

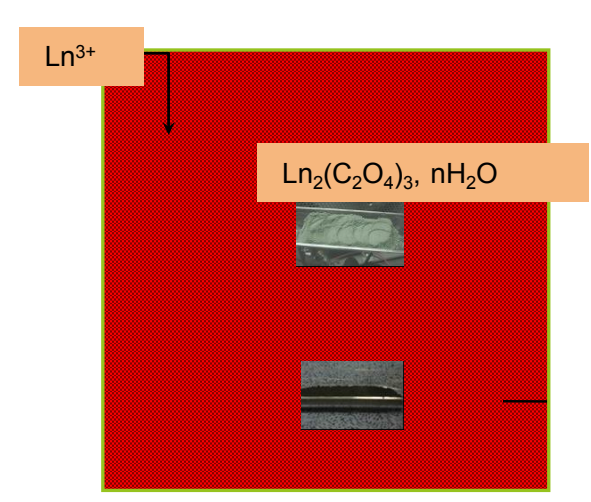

- CERMET = porous microspheres of cerium oxide incorporating other REO and metallic $\mathrm{Ni}$

- Numerous applications replacing PGM in catalysis (steam methane reforming, hydrogenation)

- Straight-forward synthetic process (CEA patent)

- No need for SX purification of input leaching solutions

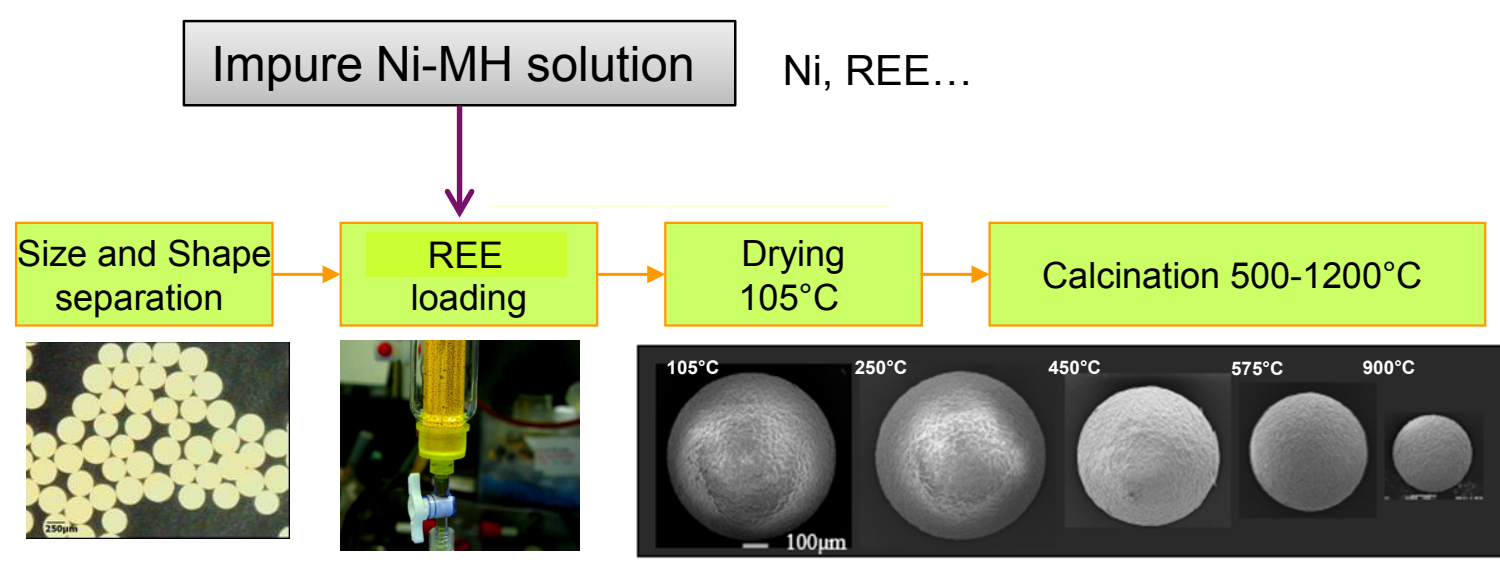

CERMET particles with controlled parameters (size, porosity, exchange area)

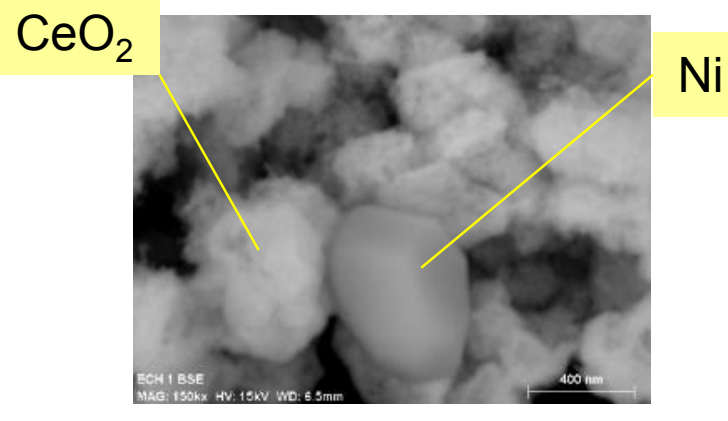

Caravaca, Catalysts, 2017, 7(12), 368

T. Delahaye, patent EP3034209 
Electroreduction in molten chloride of $\mathrm{Nd}$ or Dy suffers from low faradic yields $(<40 \%)$ due to the presence of $\mathrm{M}^{2+}$ species

Use of transient electroanalytical techniques (voltammetry reversal chronopotentiometry, chronoamperometry...)

to optimize the experimental conditions:

- Salt composition (chloride / fluoride)

- Temperature

- RE concentration

- Current and current density

Metal deposition tests to evaluate the process efficiency:

- Faradic yield

- Product purity

- Cell materials compatibility

Gram-scale production of pure or mixed metallic REE with Faradic efficiency $\approx 80 \%$
Cyclic voltammetry in molten chloride salt
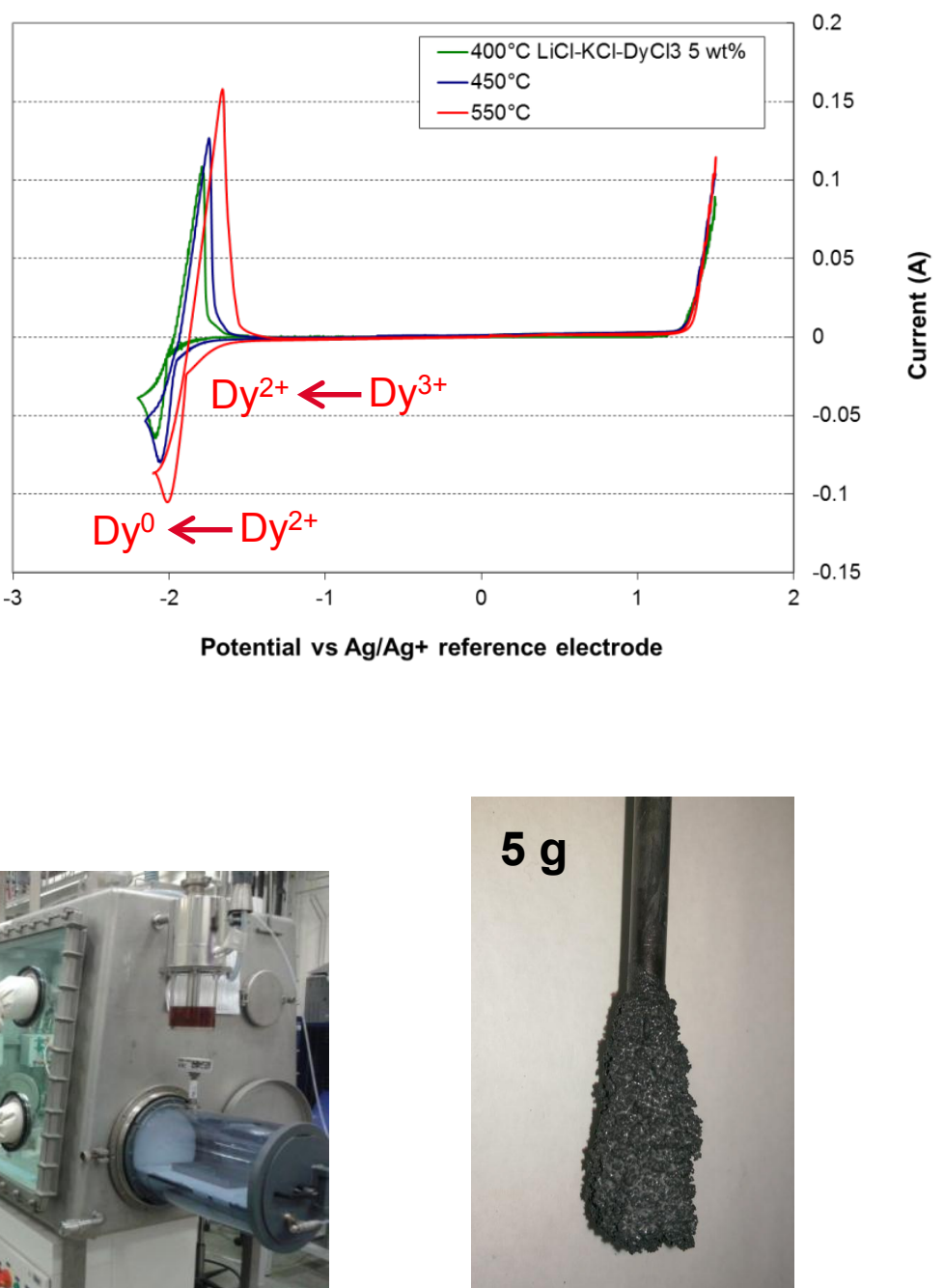
Hydrometallurgical recovery of REO from NdFeB magnet scraps (excluding pyrometallurgical steps)

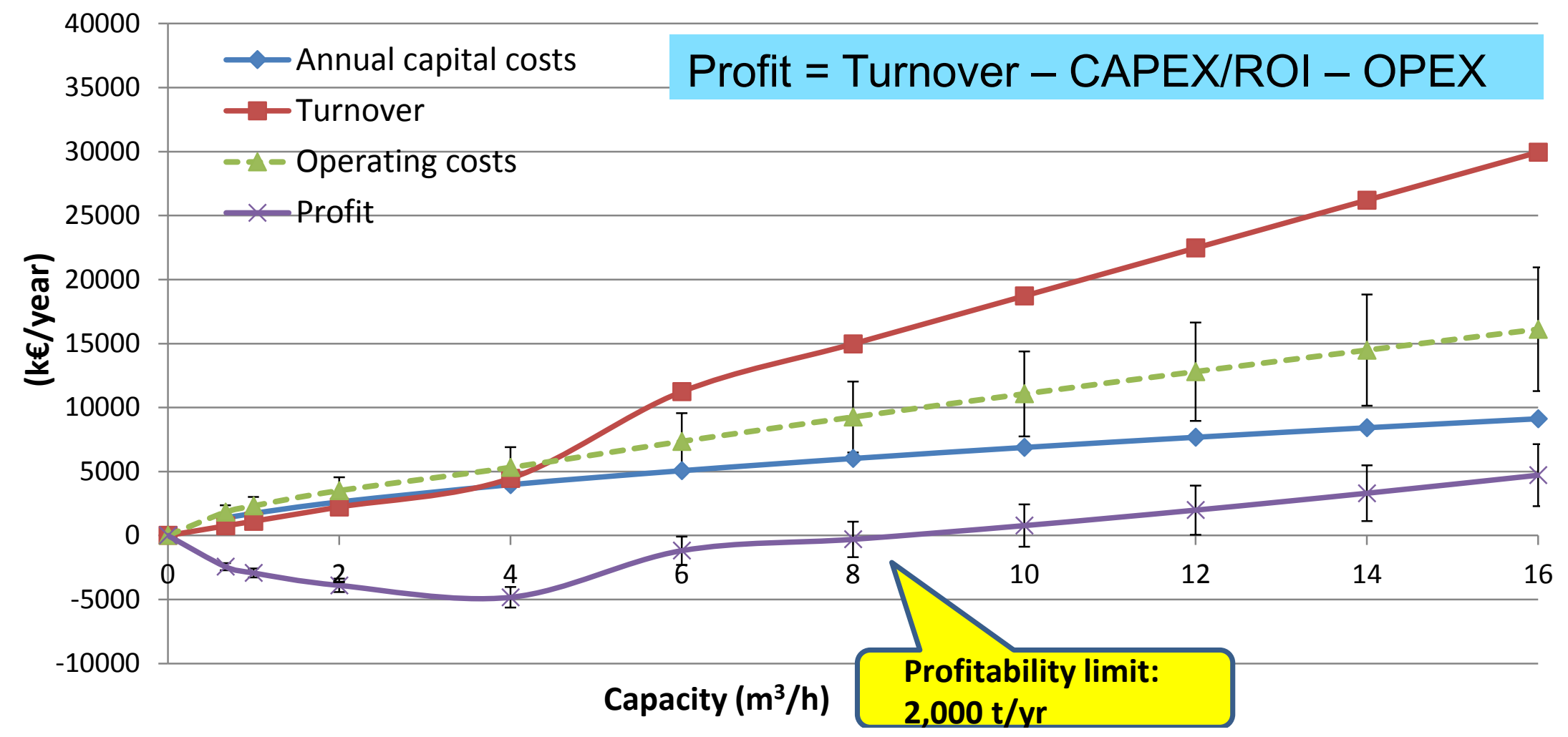

- The profitability limit can be shifted to a lower capacity (300 t/yr) with an optimised process

- Liquid waste treatment cost has to be further assessed, depending on local regulations (discharge of $\mathrm{NO}^{3-}$ is strictly supervised)
- Non optimised conditions

- Rol $=3$ years

- Careful hypothesis for REEs prices $\mathrm{Nd}_{2} \mathrm{O}_{3} 50$ US $\$ / \mathrm{kg} ; \mathrm{Dy}_{2} \mathrm{O}_{3}=300$ US $\$ / \mathrm{kg}$

- Work in 5 shifts for throughput $>5 \mathrm{~m}^{3} / \mathrm{h}$

- $15 \%$ uncertainty on operating costs 
- Development of two REE separation process from permanent magnets and spent NiMH batteries

Demonstration of the scientific feasibility of REE recovery by SX without preliminary separation of transition metal impurities by precipitation

- Pilot scale production (TRL 5) of highly pure Dy and Nd/Pr solutions from used magnets

- Experiments in progress on NiMH battery flowsheet process

REE conversion to oxides (oxalic precipitation) and CERMETs

Molten salt electrolysis for producing pure or mixed metallic REE

- Technical-economic study of the process for cost and rentability evaluation

REE recycling from magnets involving hydrometallurgy and SX doesn't seem currently profitable

- Low volume of small magnets from available, easily dismantled WEEE

- High lifetime of larger magnet-containing products (wind turbines, HEV motors)

- REE recycling from spent $\mathrm{NiMH}$ batteries might be interesting

- Simple, compact flowsheet integrated in existing battery recycling process

- Production of value-added products (cermet...)

- TEA needed to confirm these hypotheses 
Acknowledgments

\section{CEA / DEN}

V. Haquin M-T. Duchesne

V. Pacary

M. Montuir

D. Rinsant

G. Mossand

D. Hartmann

L. Diaz

\section{CEA / DRT}

E. Billy

P. Feydi

R. Laucournet

\section{SNAM}

N. Coppey

\section{Thank you for your attention}




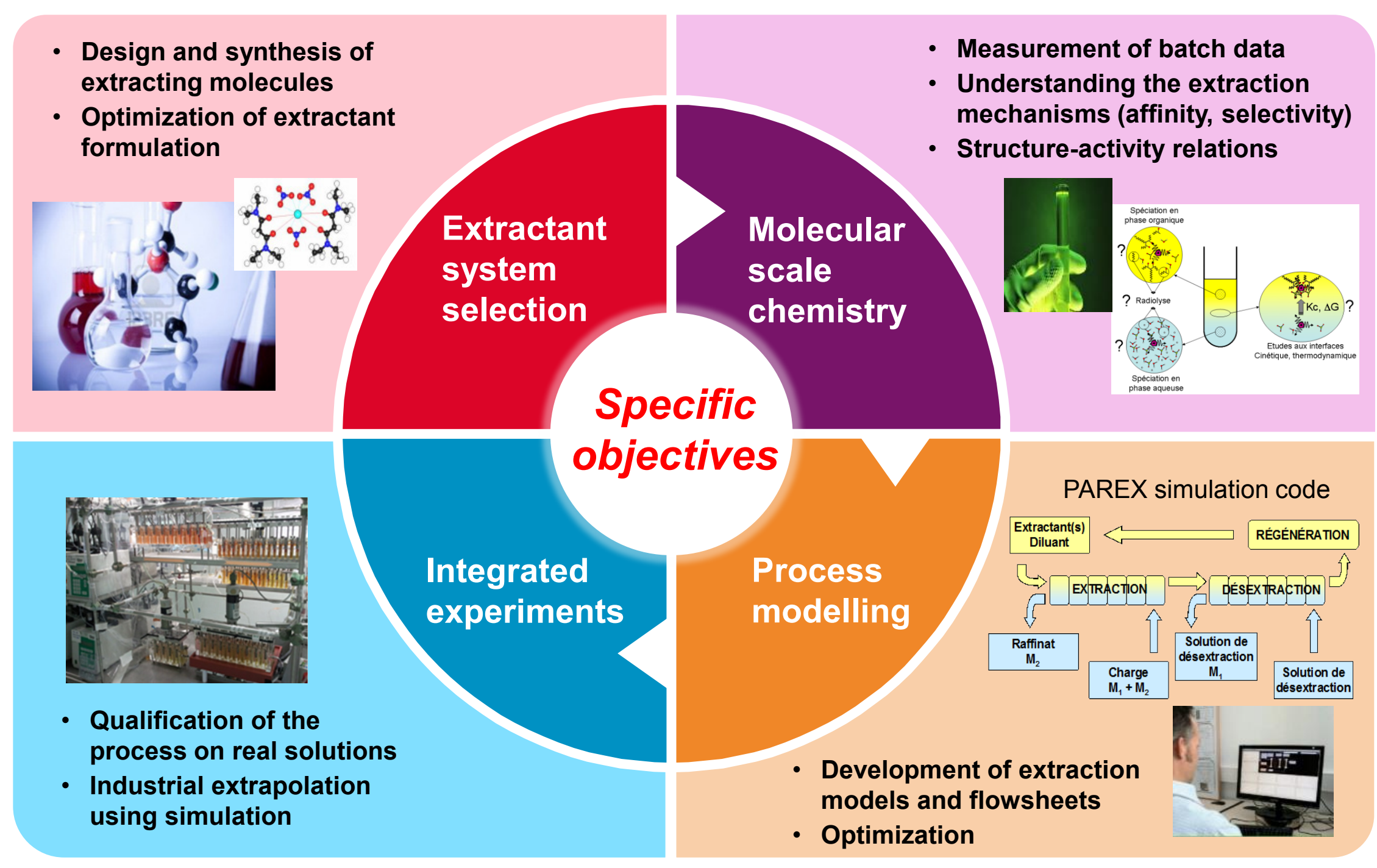




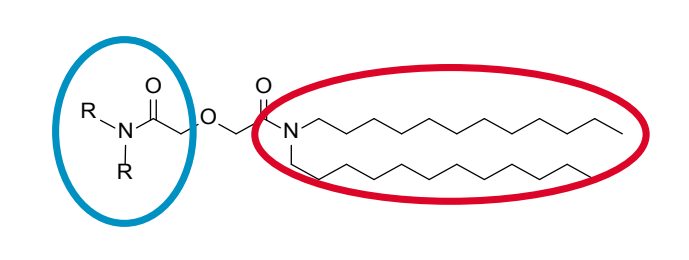<smiles>CCCCCCCN(CCCC)C(=O)COCC(=O)N(CC)CC</smiles>

N,N,-diethyl-N',N'-didodecyl DGA $(\mathrm{N}, \mathrm{N}-\mathrm{E})$

$$
\sim_{N^{\mathrm{C}}}^{\mathrm{O}} \mathrm{C}_{\mathrm{C}_{12} \mathrm{H}_{25}}^{\mathrm{O}}
$$

N,N,-dipropyl-N',N'-didodecyl DGA $(\mathrm{N}, \mathrm{N}-\mathrm{P})$

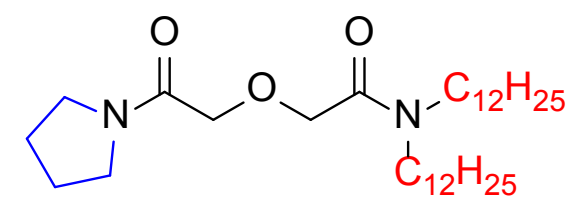

N-pyrrolidinyl-N',N'-didodecyl DGA (N-Py)

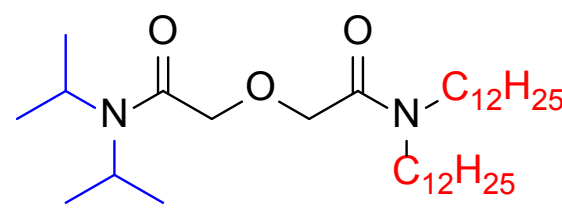

$\mathrm{N}, \mathrm{N}$, -diisopropyl-N',N'-didodecyl DGA $(\mathrm{N}, \mathrm{N}-\mathrm{iP})$

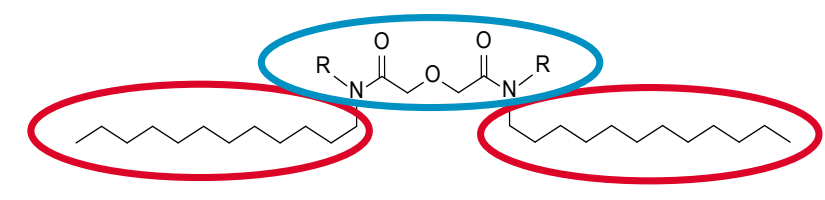

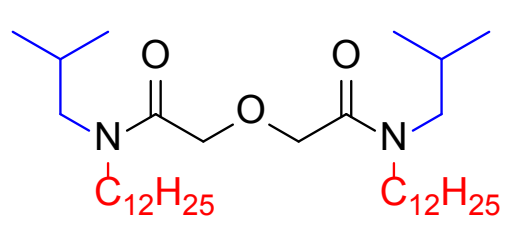

$\mathrm{N}, \mathrm{N}^{\prime},-$ diisobutyl-N,N'-didodecyl DGA $\left(\mathrm{N}, \mathrm{N}^{\prime}-\mathrm{iB}\right)$

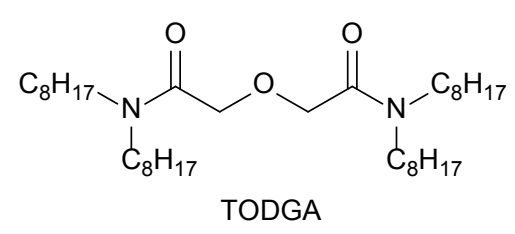

Reference extractant

$$
\sim_{\mathrm{C}_{12} \mathrm{H}_{25}}^{\mathrm{O}} \overbrace{\mathrm{C}_{12} \mathrm{H}_{25}}^{\mathrm{O}}
$$

$\mathrm{N}, \mathrm{N}^{\prime},-$ dibutyl-N,N'-didodecyl DGA $\left(\mathrm{N}, \mathrm{N}^{\prime}-\mathrm{B}\right)$

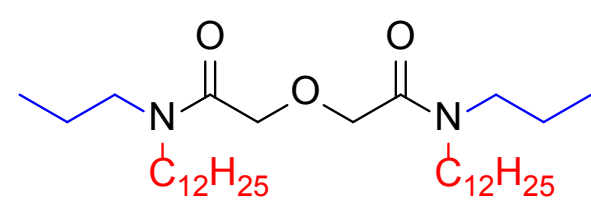

N,N',-dipropyl-N,N'-didodecyl DGA $\left(\mathrm{N}, \mathrm{N}^{\prime}-\mathrm{P}\right)$ 


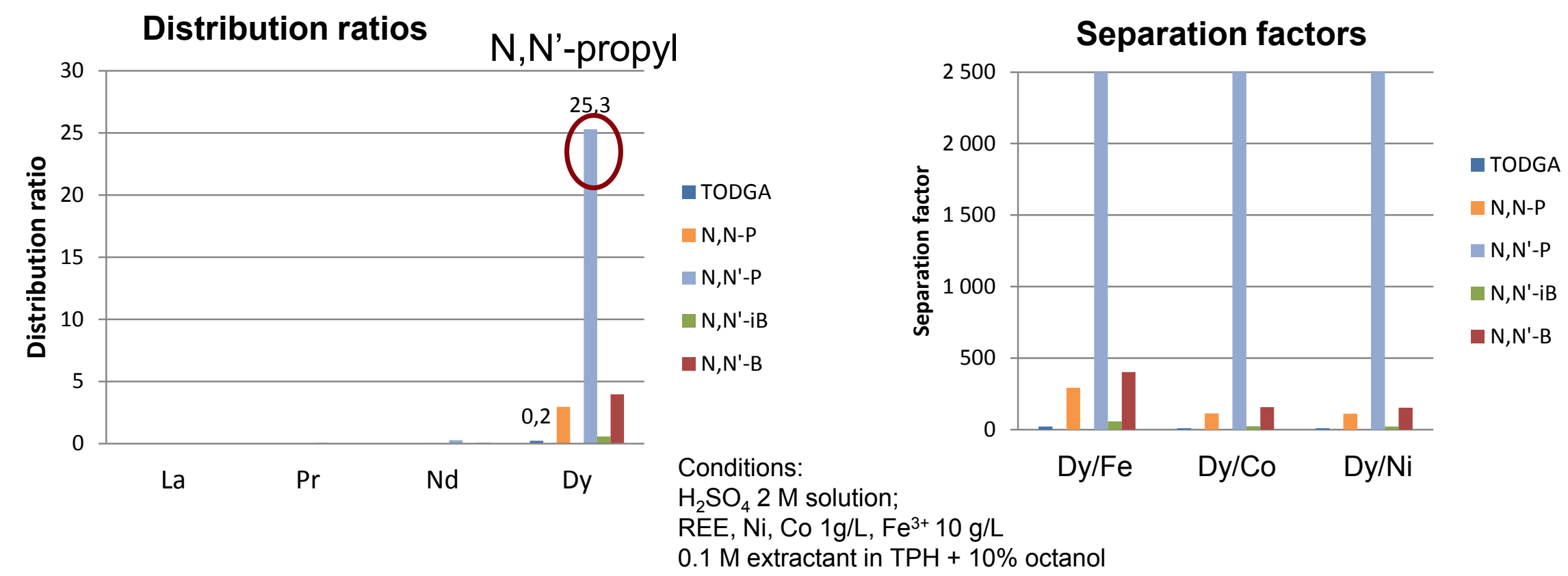

- Much lower extraction in $2 \mathrm{M}$ sulfuric acid compared to $3 \mathrm{M}$ nitric acid solutions

- Only heavy REE can be selectively extracted, no light-REE extraction

E Remarkable improvement of extraction compared to TODGA (x 100) for N,N'-propyl DGA ( $D_{D y}=25$ for N,N'-propyl DGA)

- Excellent separation factors $\mathrm{Dy} / \mathrm{Fe}, \mathrm{Co}, \mathrm{Ni}$

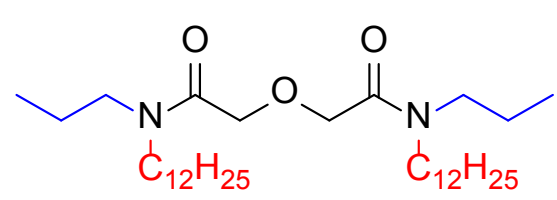

N,N'-propyl 


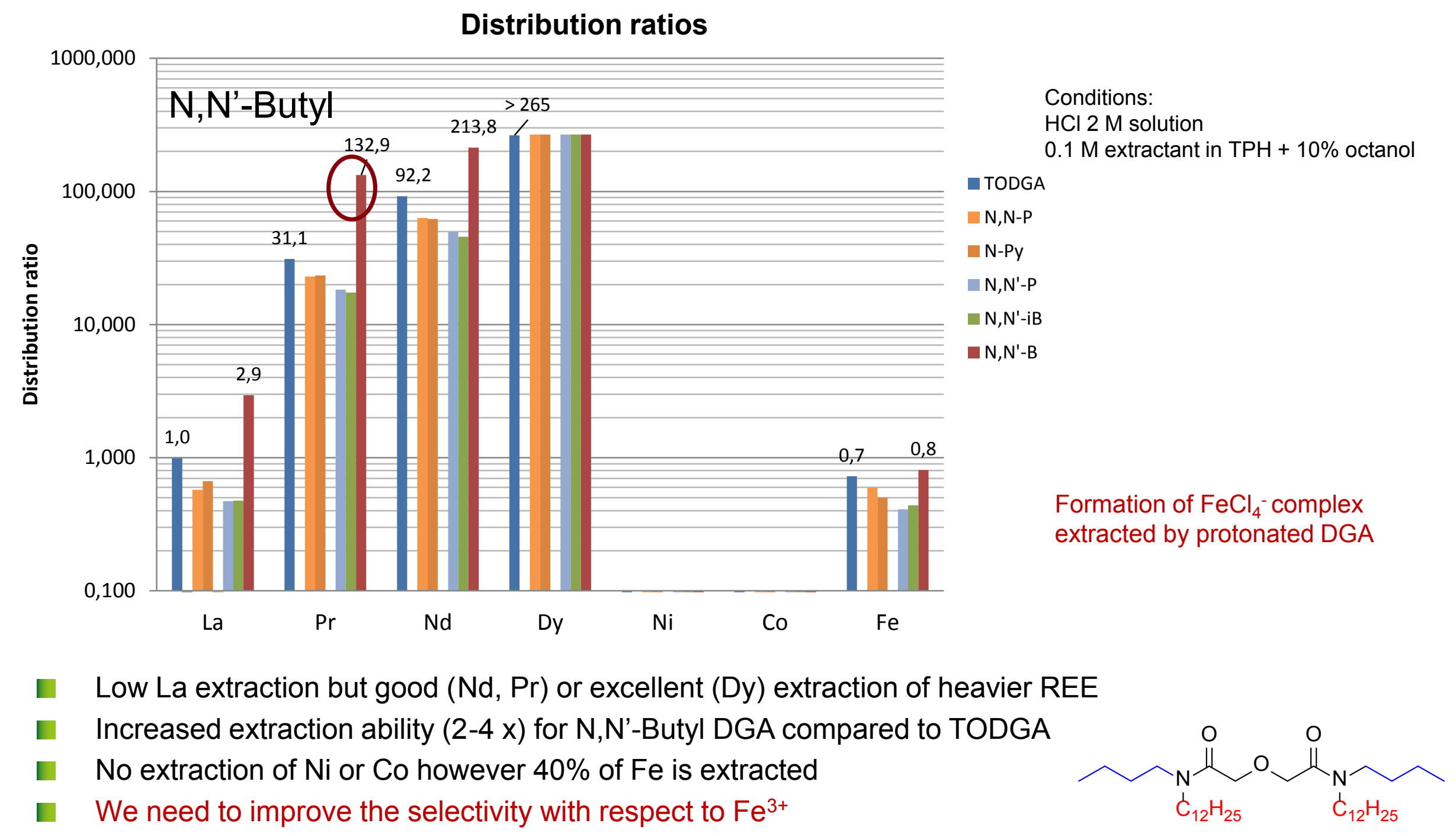

